\title{
|لبحث: "11"
}

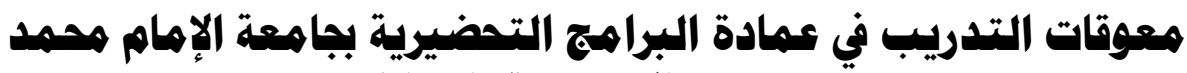

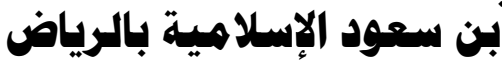

$$
\begin{aligned}
& \text { : إحطاك }
\end{aligned}
$$

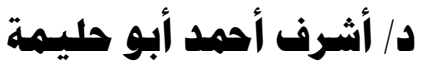

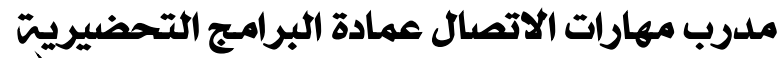

$$
\begin{aligned}
& \text { بجامعت الإمام محمد بن سعود الإسلاميتَ بالرياض التحفيرية (سابقا) }
\end{aligned}
$$





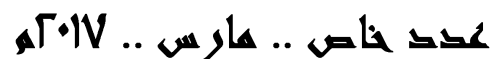

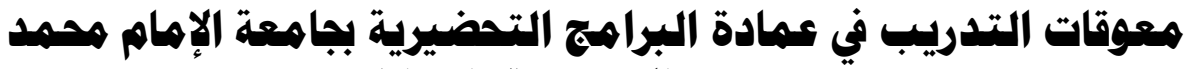 بن السعود الإسلاهية بالرياض
}

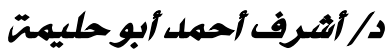

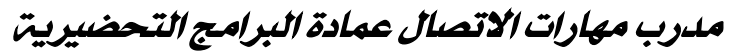

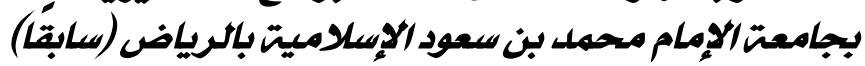

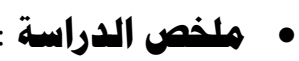

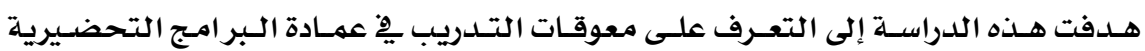

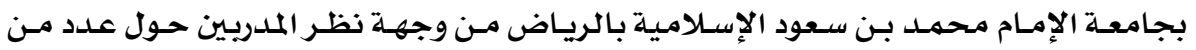

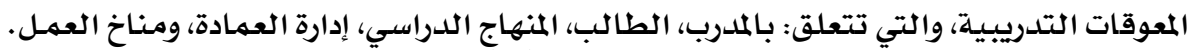

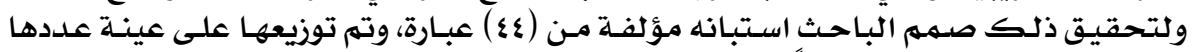

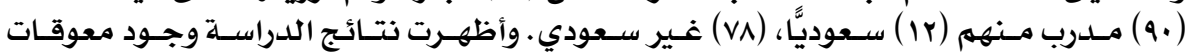

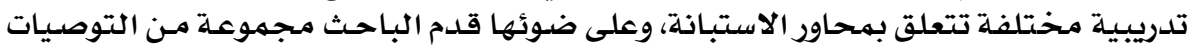

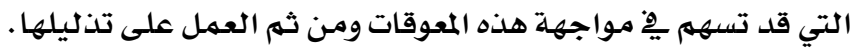

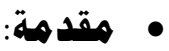

يعد التدريب داخل السنوات التحضـيريـة نظامـاً فرعيَّا مـن التعليهم الجـامعي،

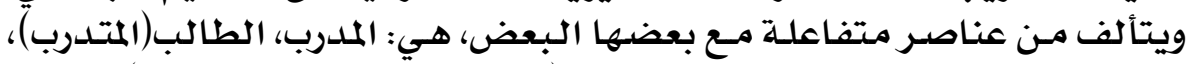

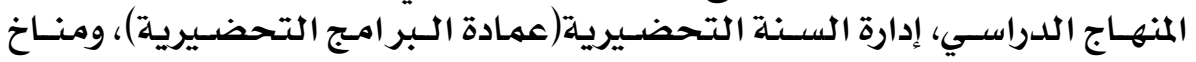

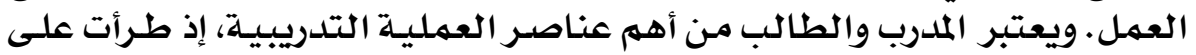

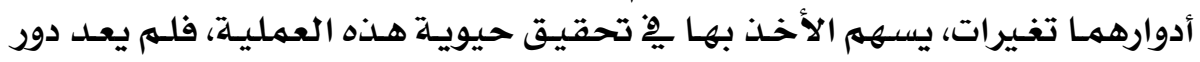

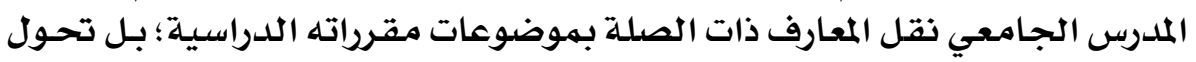

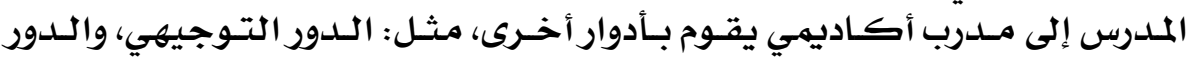

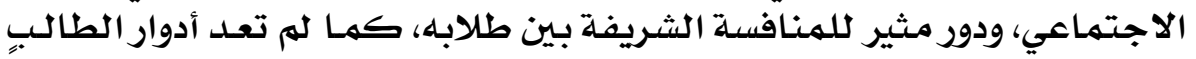

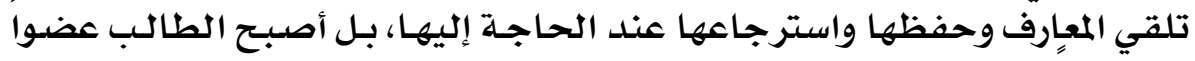

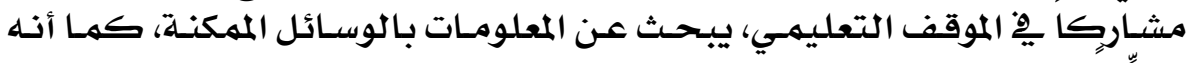

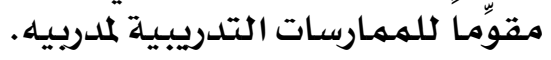

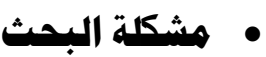

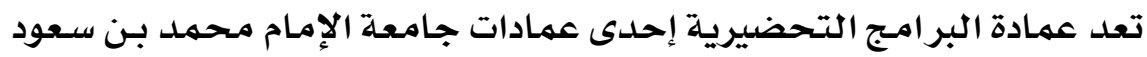

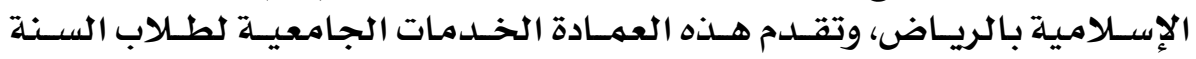

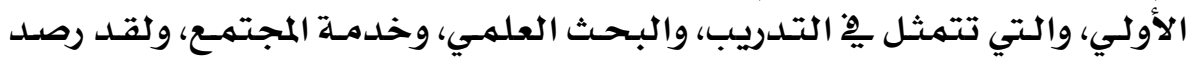

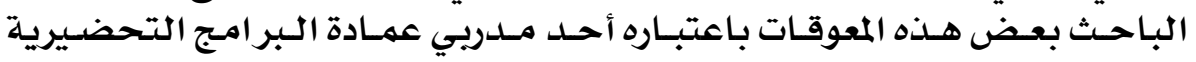

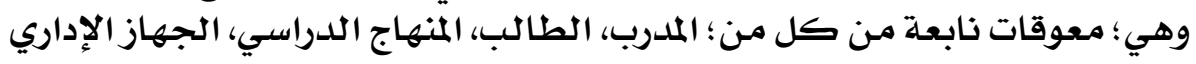

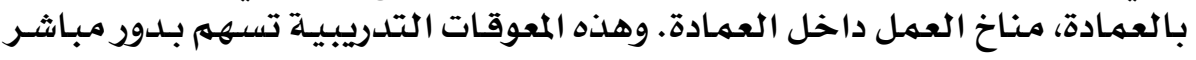

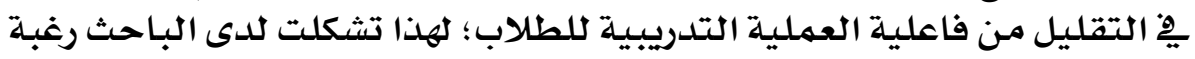

\section{$\varepsilon Y V$}




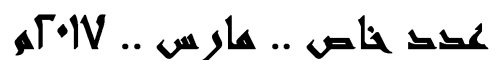

يِّ رصد معوقات التدريب بعمادة البرامج التحضيرية بجامعة الإمـام محمـد بن سعود الإسلامية بالرياض.

ويحدد الباحث مشكلة الدراسة الحالية يِّ السؤال الرئيس التالي:

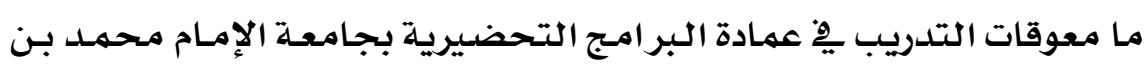
سعود الإسلامية بالرياض و ويتفرع عن هذات التها السؤال الأسئلة التالية:

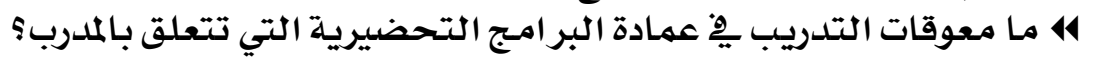

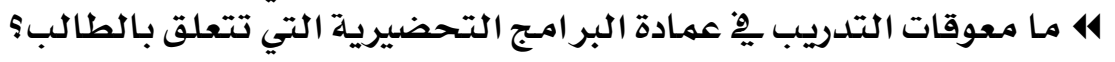

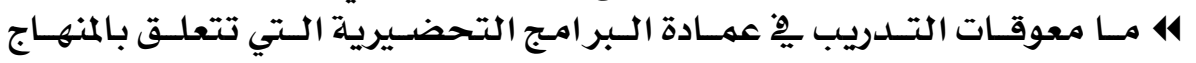

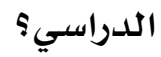

414 ما معوقات التدريب بِ عمادة البرامج التحضيرية التي تتعلق بالإدارة ؟

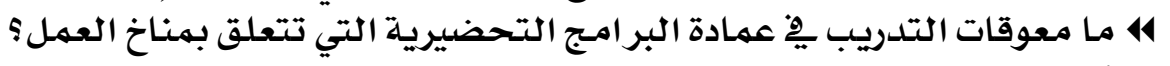
• أهداف الدراسة: تهدف الدراسة إلى:

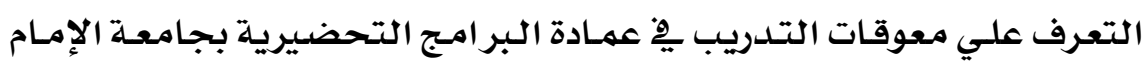
محمد بن سعود الإسلامية. • أهمية الدراسة: تتضح ألهمية الدهية الدراسة فيسما يلي:

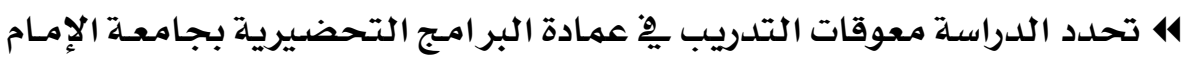

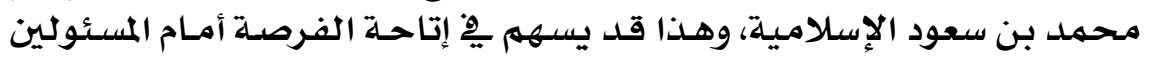
لحلها.

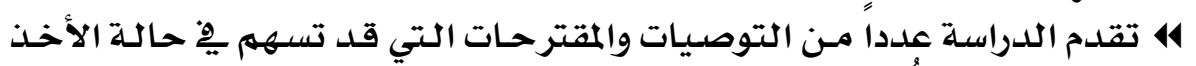

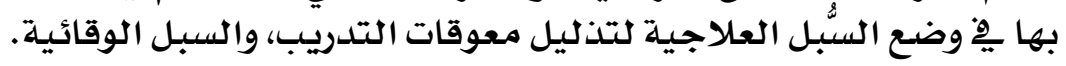

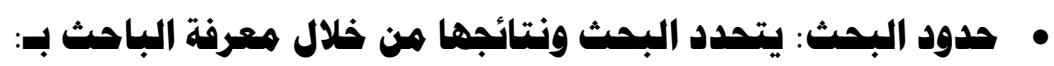

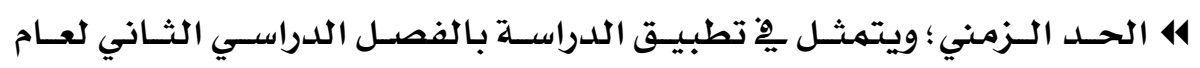

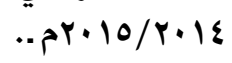
4 الحد المكاني؛ ويتمثل بِّ عمادة البر امجج التحضيرية بجامعة الإمام محمـد بن

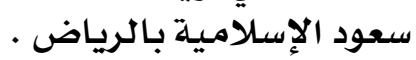
4 الحد البشري؛ ويتمثل ِِّْ أعضاء هيئة التدريس(المدربين)

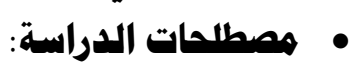

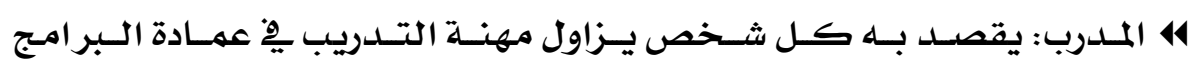

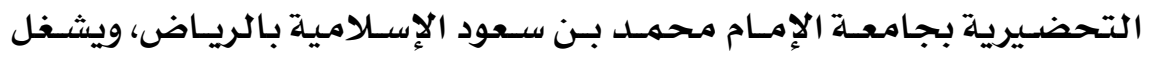

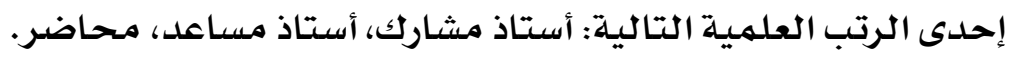

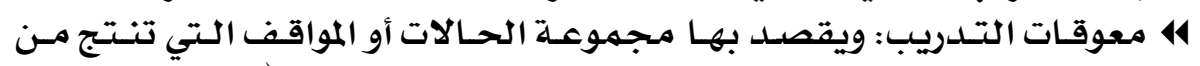

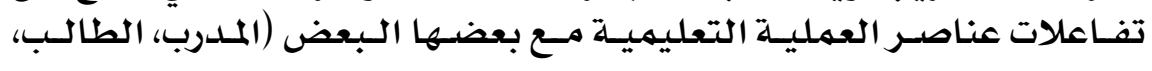

\section{$\varepsilon Y \wedge$}




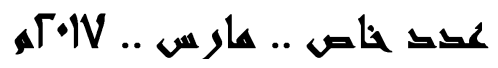

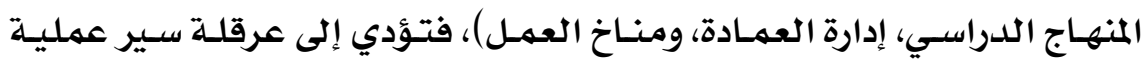

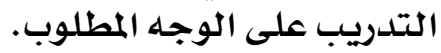

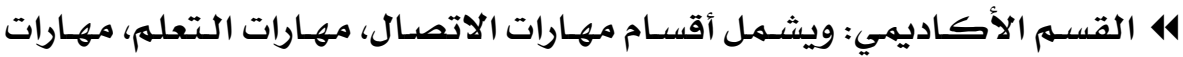

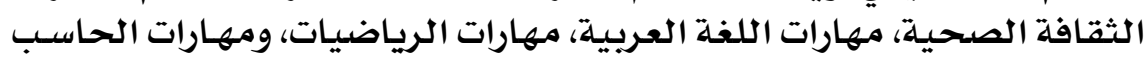

$$
\text { الآلي. }
$$

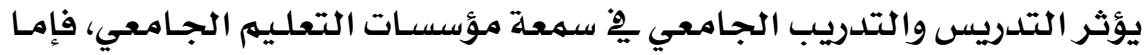

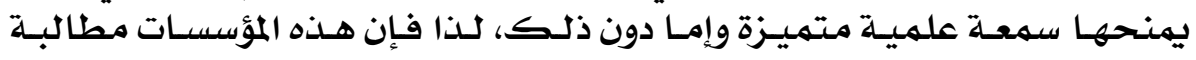

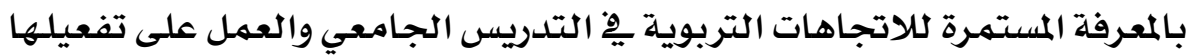

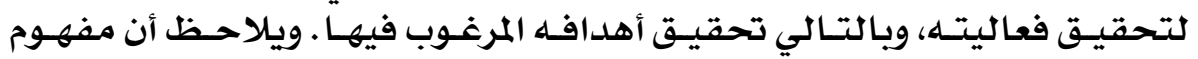

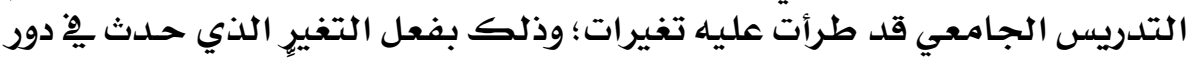

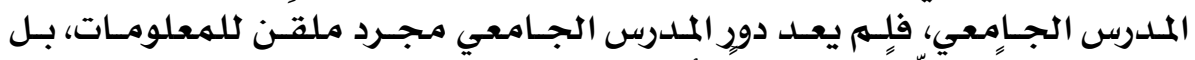

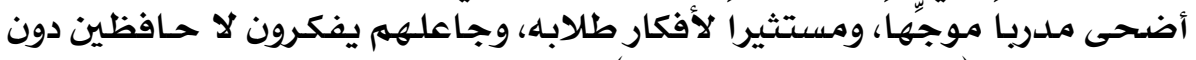
فهم أو تطبيق (عايث زيتون، 1990 : 19 19: ).

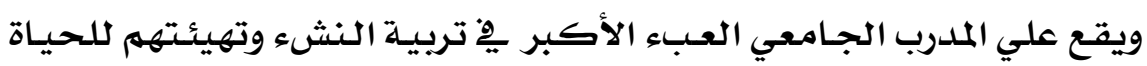

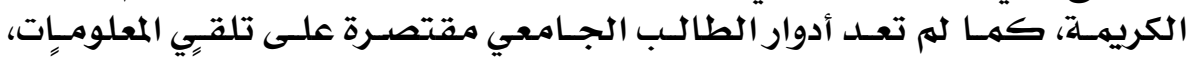

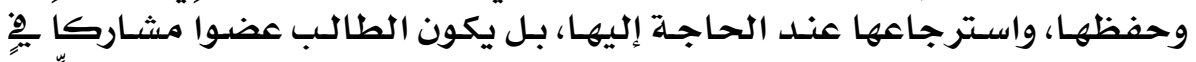

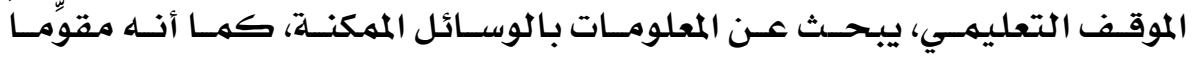
للهممارسات التدريبية لمدروسية بيحيه.

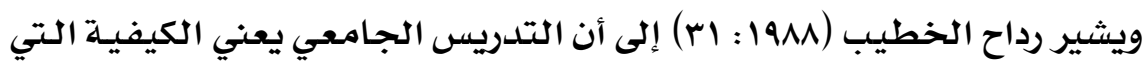

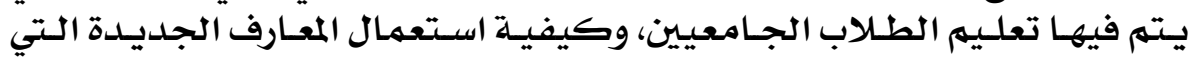
تتفجر كل يوم وبسرعة متزئرايدة.

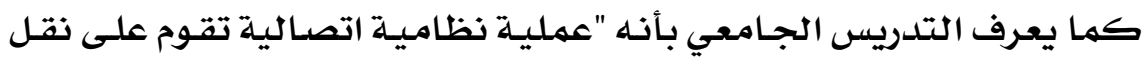

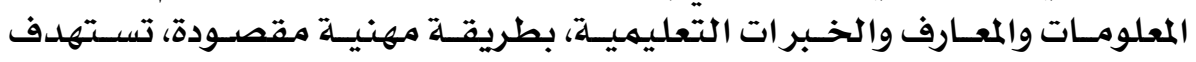

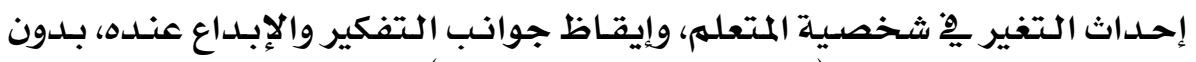

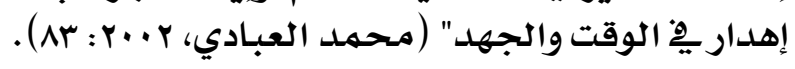

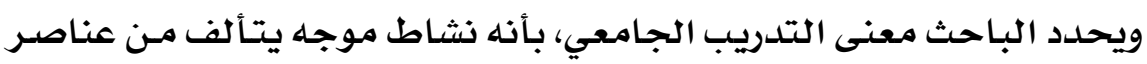

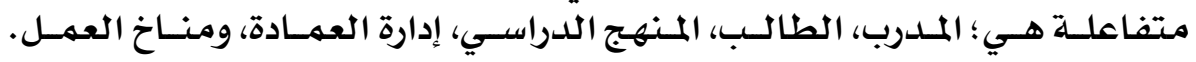

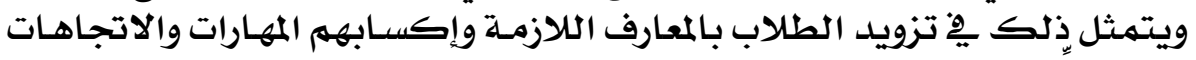

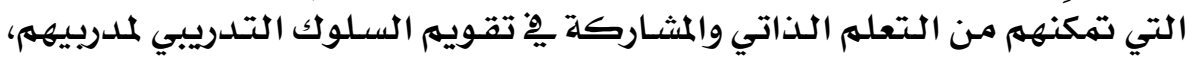

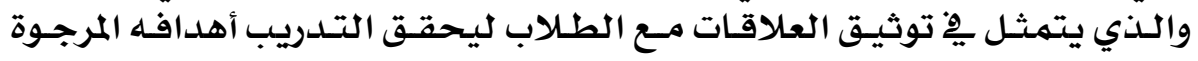

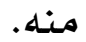

\section{$\varepsilon$ Y}


عقد خاص .. هارس .. VIיזم,

\section{• ويمكن إبراز أهمية التدريب الجاهعِي في عدد هن النقاط هنها:}

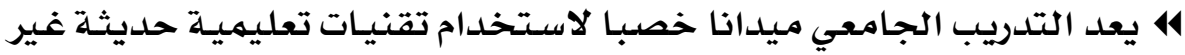

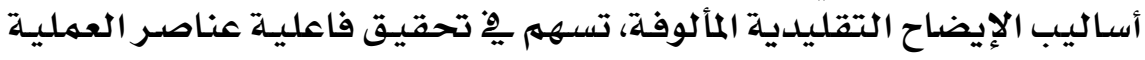

$$
\text { التدريسية الإيضاح. }
$$

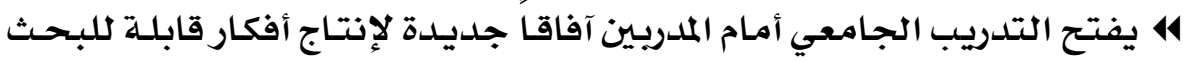

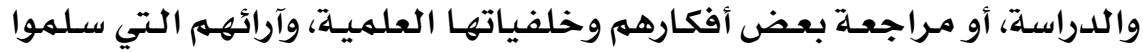

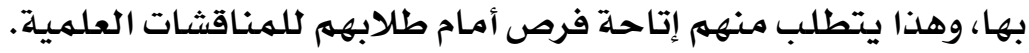

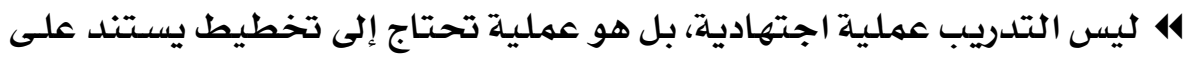

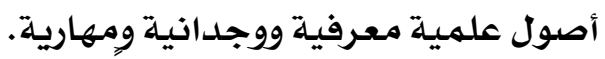

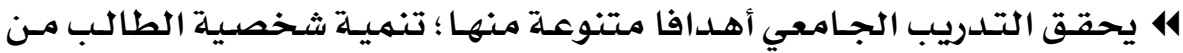

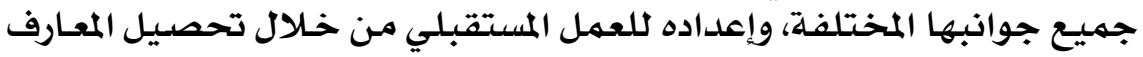

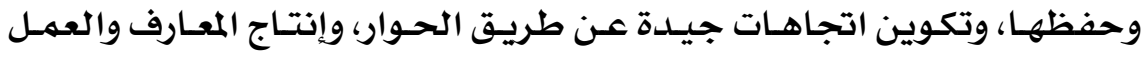

$$
\text { على إثرائها. }
$$

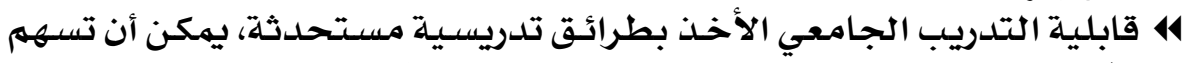

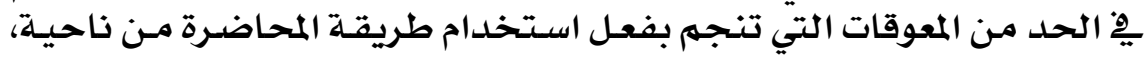

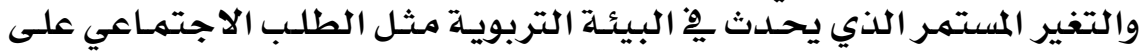

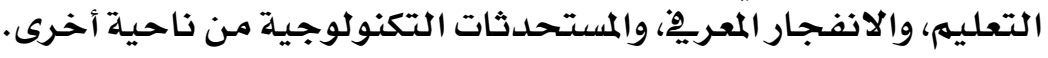

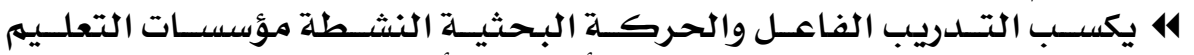

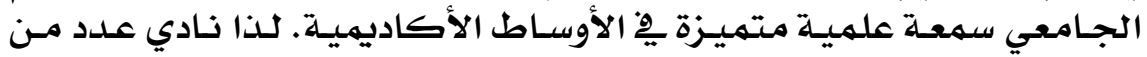

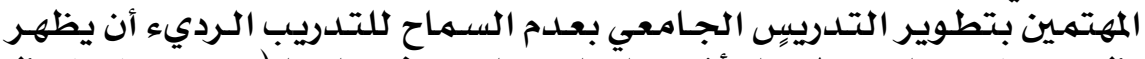

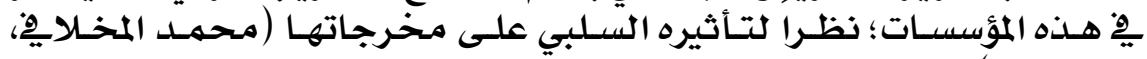
.)(11T:r...r

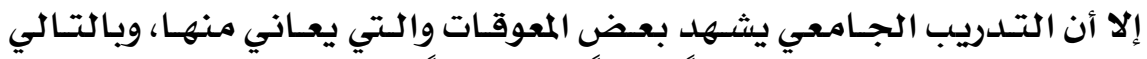

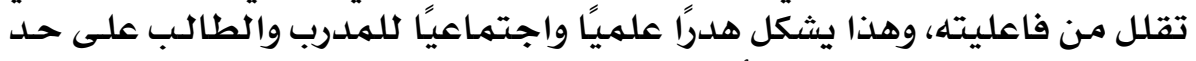

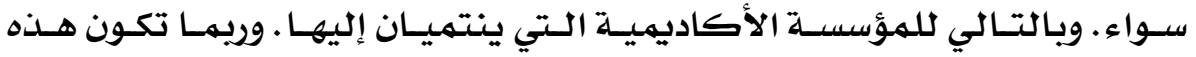

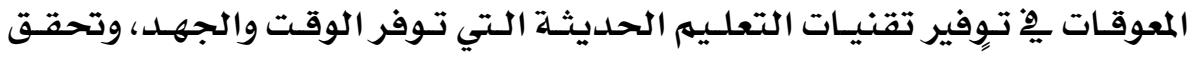

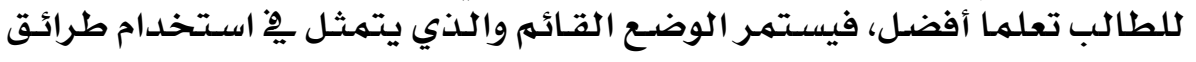
تدريسية ووسائل إيضاح تقليدية.

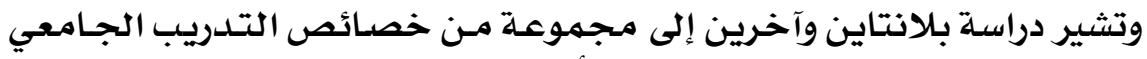

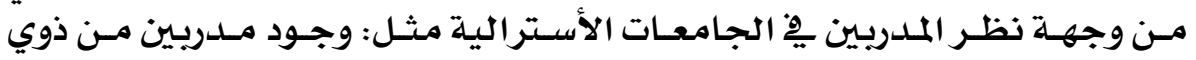

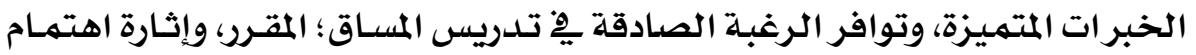

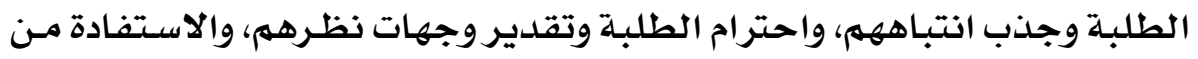

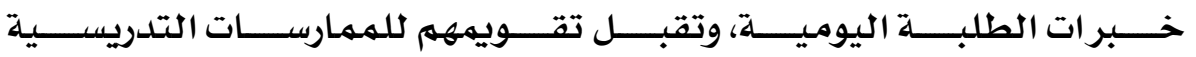
ملمدرسيهي (Ballantyne , et al, 1999:244-247)

\section{$\varepsilon r$.}




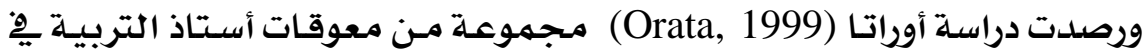

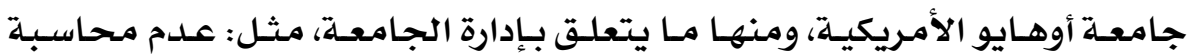

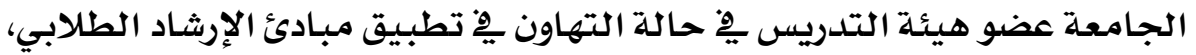

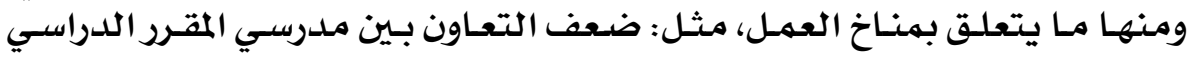

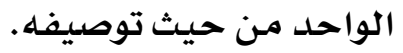

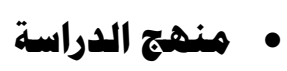

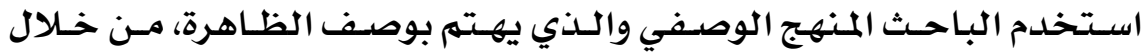

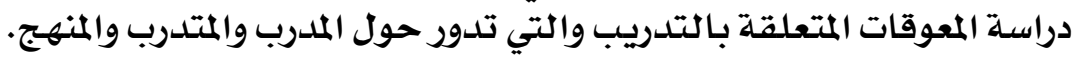

\section{• • هجتمع الدراسة:}

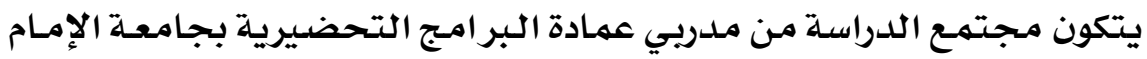

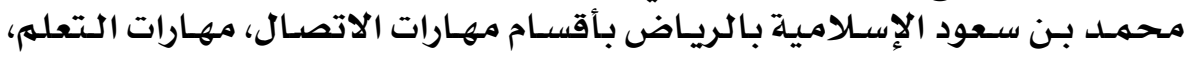

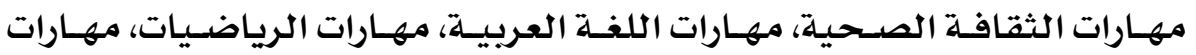

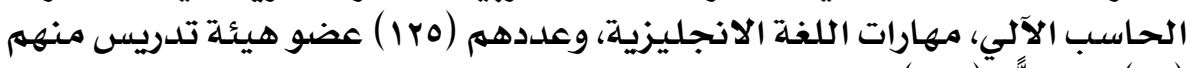

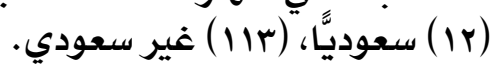

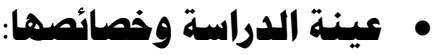

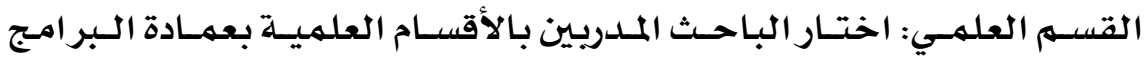

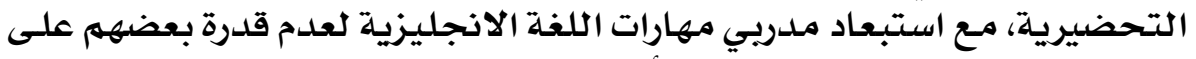

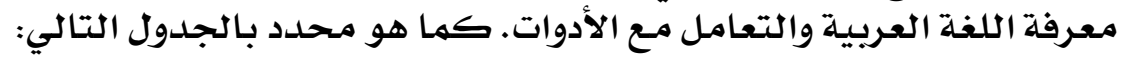

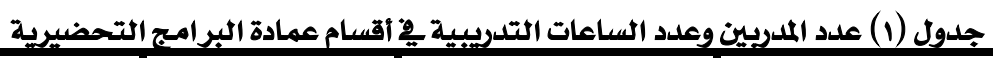

\begin{tabular}{|c|c|c|c|}
\hline النسبة ٪ & عدد المدربين بالقسم & $\begin{array}{c}\text { عدد الساعات التدريبية } \\
\text { بالأسبوع }\end{array}$ & القسم العلمي \\
\hline YA.9 & ry & $\wedge$ & مهارات الرياضيات \\
\hline rr.r & rq & $\wedge$ & مهارات الحاسب الآلي \\
\hline ir.r & ir & $\varepsilon$ & مهارات الاتصال \\
\hline 1. & 9 & $r$ & مهارات التعلم والتفكير \\
\hline V.A & $\checkmark$ & $r$ & مهارات اللغة العربية \\
\hline$v . \Lambda$ & $v$ & $r$ & مهارات الثقافة الصحية \\
\hline $1 \ldots$ & 9. & $r V$ & المجموع \\
\hline
\end{tabular}

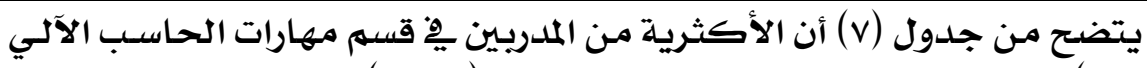

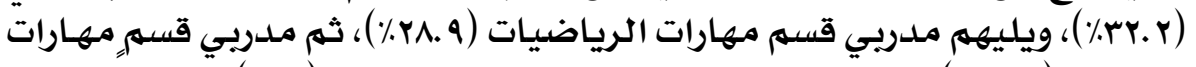

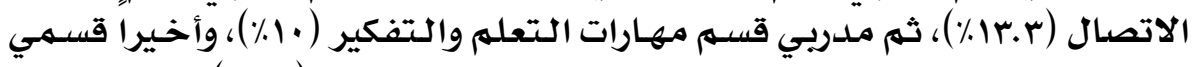

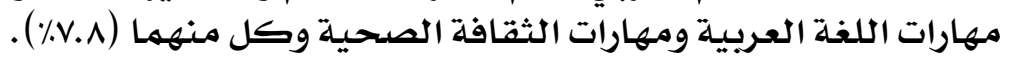

\section{$\varepsilon \Psi 1$}




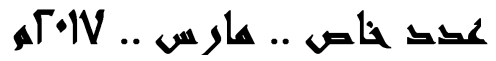

\section{• أدوات الدراسة والخصائص السيكوهترية لها}

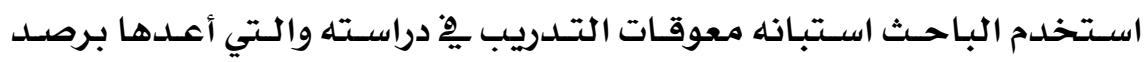

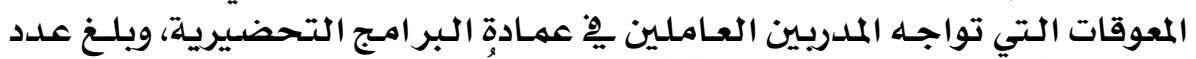

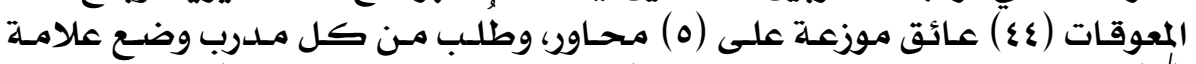

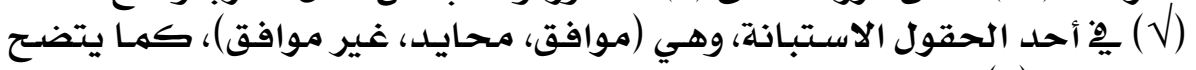
من جدول (r) التالي:

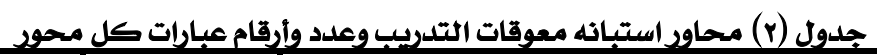

\begin{tabular}{|c|c|c|c|}
\hline 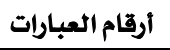 & 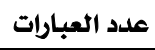 & المحور - المو & p \\
\hline $11-1$ & 11 & معوقات التدريب التي تتعلق بالمدرب & 1 \\
\hline$r I-i r$ & 1. & معوقات التدريب التي تتعلق بالطالب & r \\
\hline$r 9-r r$ & $\wedge$ & معوقات التدريب التي تتعلق بالمنهاج الدراسي & $r$ \\
\hline$r q-r$. & $\checkmark$ & معوقات التدريب التي تتعلق بإدارة العمادة & $\varepsilon$ \\
\hline$\varepsilon \varepsilon-r v$ & $\wedge$ & معوقات التدريب التي تتعلق بمناخ العمل & 。 \\
\hline
\end{tabular}

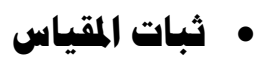

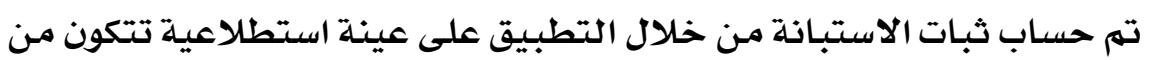

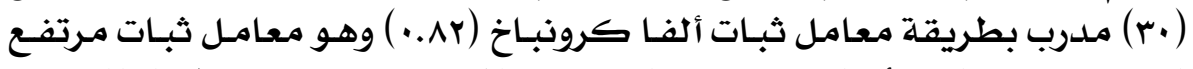

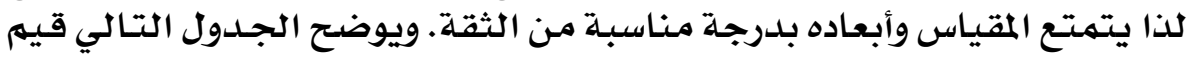
ثبات كل محتور مـن المحاور.

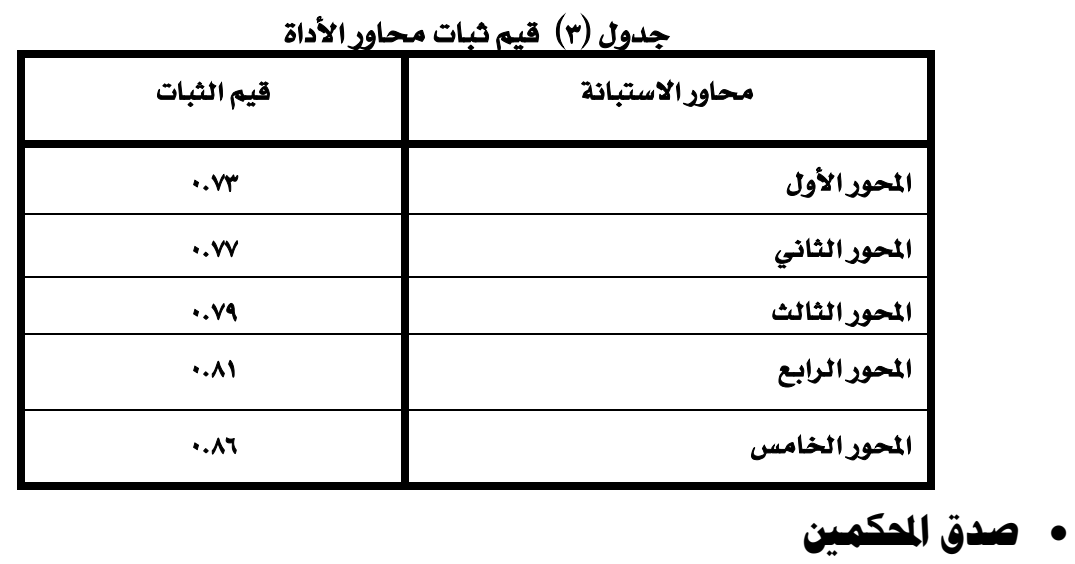

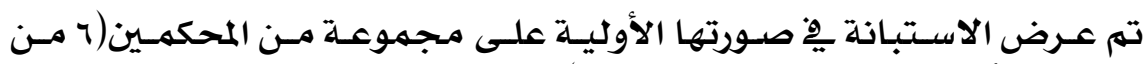

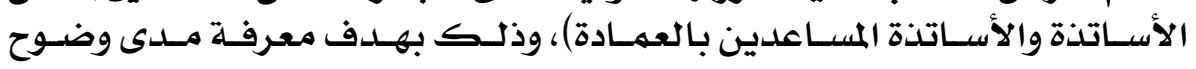

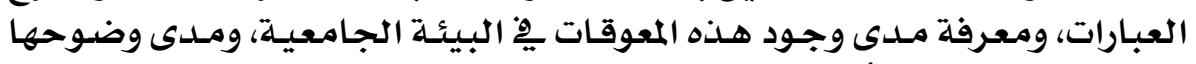

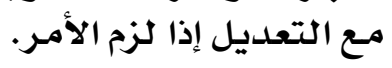

\section{$\varepsilon \Psi Y$}

أوراق عهل وبموث المؤتهر الدولي الأول لمركز تنسية قدرات أعضاء هيئة التدريس والقيادات بقاهعة بنها .. ه هارس rا. مrم 


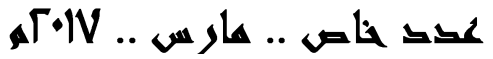

\section{• • • معاهل الاتساق الداخلي:}

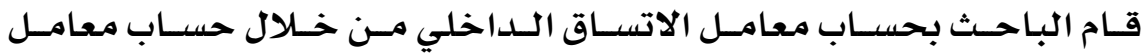

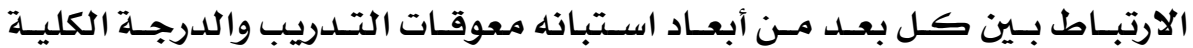

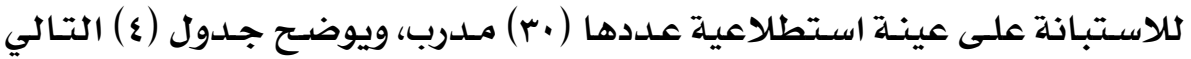

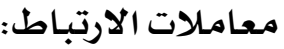

جدول(ع) معاملات الارتباط لعبارات استبانه معوقات التدريب ِِ عمادة البرامج التحضيرية

\begin{tabular}{|c|c|c|c|c|c|c|c|c|c|}
\hline \multicolumn{2}{|c|}{ المحور الخامس } & \multicolumn{2}{|c|}{ المحور الرابع } & \multicolumn{2}{|c|}{ المحور الثالث } & \multicolumn{2}{|c|}{ المحور الثاني } & \multicolumn{2}{|c|}{ المحور الأول } \\
\hline التثبعات & رقم العبارة & التثشبعات & العبارة & التثبعات & رالعبارة & التثبعات & رالعبارة & التثبعات & رلعبارة \\
\hline. .47 & rv & .04 & r. & $\cdot .4$ & rr & $\cdot . £ 9$ & ir & $\cdot .1$ & 1 \\
\hline. .07 & re & • & $\mu$ & $\because 0 \leqslant$ & rT &. .47 & 14 & ع & r \\
\hline. .07 & rq &. .09 & rY & דצ & $Y \leq$ & .04 & $1 \varepsilon$ & $\cdot . \leqslant \leqslant$ & $r$ \\
\hline$\cdot . \leqslant$ & $\varepsilon$. & $\cdot .4$ & r & $\cdot . \leqslant$ & ro & $\cdot \leqslant r$ & 10 & $\cdot . \leqslant 7$ & $\varepsilon$ \\
\hline$\because .09$ & \&1 & .04 & $r \varepsilon$ & .09 & ri & $\because \leqslant V$ & 17 & .07 & 0 \\
\hline$\cdot . \leqslant V$ & $\leqslant r$ & $\cdot . \Gamma \varepsilon$ & ro & $\cdot .47$ & YV &.$\mu r$ & IV &. .07 & 7 \\
\hline.${ }^{\mu r}$ & $\varepsilon r$ & $\cdot r v$ & m & .07 & rA &. .49 & 11 & $\cdot . \leqslant \varepsilon$ & v \\
\hline. .49 & \& & & & $.0 \leqslant$ & rq & . rr & 19 & $\because .09$ & $\wedge$ \\
\hline & & & & & & $\cdot . £$ & r. & $\cdot .47$ & 9 \\
\hline & & & & & & $\because .09$ & $r 1$ & .04 & 1. \\
\hline & & & & & & & & $\because 0 \leqslant$ & 11 \\
\hline
\end{tabular}

بمعنى أن جميع المعوقات مرتبطة بالقيه الكلية للمحاور التي تنتهي إليها. • طريقة الإجابة علي الاقيساس وتقدير الدرجة: ه يقوم المدرب بالإجابة على المقياس باختيار بديل واحد من (موافق، متردد، غير

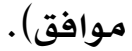

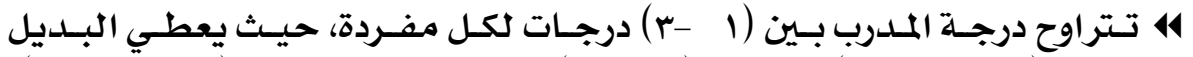

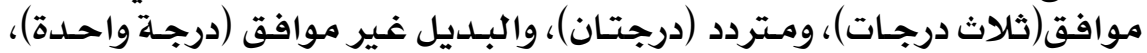

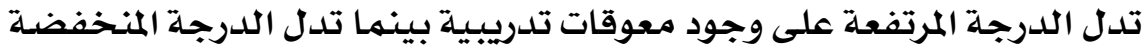

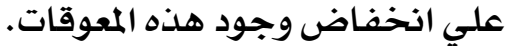

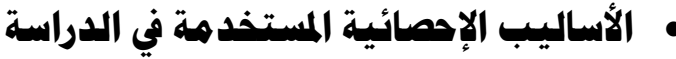

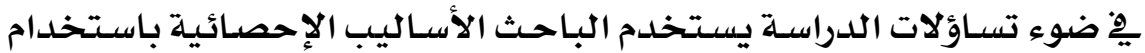

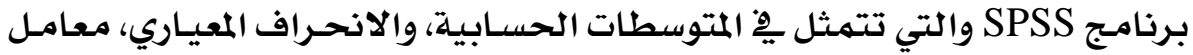
ارتباط بيرسون.

\section{$\varepsilon \Psi \mu$}


كقכ خاص .. عار س .. VIיזم,

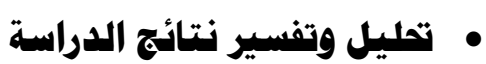

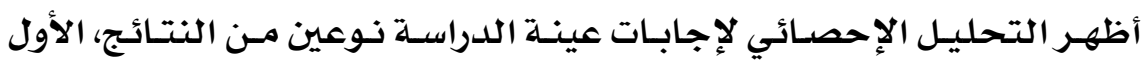

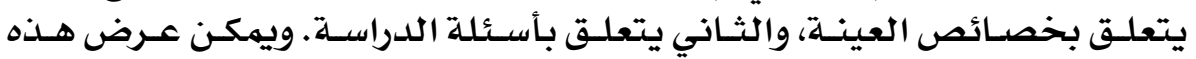

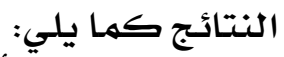
• إجابة السؤال الأول: ها هعوقات التدريب في عمادة البراهج التحضيرية الـتي

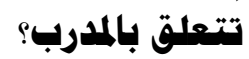

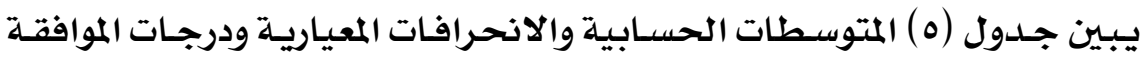
لاستجابات أفراد العينة نحو معوقات التحات التدريب التي تتعلق بالماتمرب.

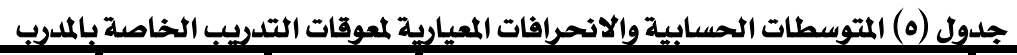

\begin{tabular}{|c|c|c|c|c|}
\hline الدرجة & المعياري & المتوسط & المعوق & العائق \\
\hline موافق &. .94 & $r .79$ & تثُتت مواعيد التلاريب لبعض المدربين & .1 \\
\hline هو افق & $.7 \varepsilon$ & Y.V $\varepsilon$ & 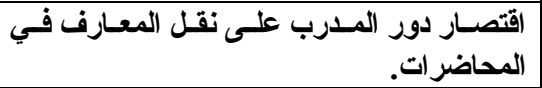 &.$r$ \\
\hline 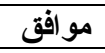 &. $.1 \mathrm{~V}$ & r.r9 & كثرة الثبع الدراسية المنوطة الددرب. &.$^{\mu}$ \\
\hline موافق & $\cdot . \mathrm{VV}$ & Y. Tะ & التدريب. الاعتـاد على المــربين غير المتفرغين في & \& \\
\hline محايد & $\cdot .{ }^{\mathrm{\mu} \Lambda}$ & 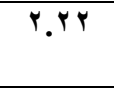 & 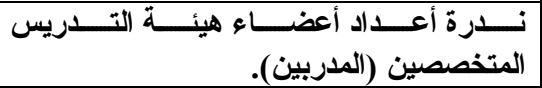 & .0 \\
\hline 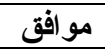 &. $\mathrm{Y \Lambda}$ & r.rA & انخفاض المؤهل العلمي لبعض العدربين. & .7 \\
\hline محايد & .. & $r . r 1$ & زيادة النصاب التدريبي للمدربين &.$^{v}$ \\
\hline محايد & .10 & Y. \& & منهج التثريبة المدرب بتجديد خلفيته العلمية عن & .^ $^{\prime}$ \\
\hline ححايد &. .19 & $1 . \wedge \varepsilon$ & 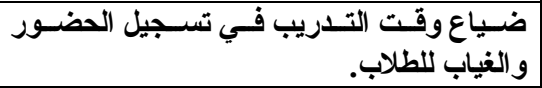 & 9 \\
\hline مو افق & $\cdot .1 \%$ & $\mathrm{r} . \mathrm{TV}$ & المدرب المقررات التدريبية بعيدة عن تخصص & 1. \\
\hline مو افق &.$\Gamma \varepsilon$ & $r . \mathrm{TV}$ & ضعف الإعداد التربوي للمدرب. & .11 \\
\hline 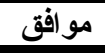 &. $\mathrm{Y \Lambda}^{\circ}$ & r.ru & لح الكلية لمعوقات التلريب التي تتعلق & الע \\
\hline
\end{tabular}

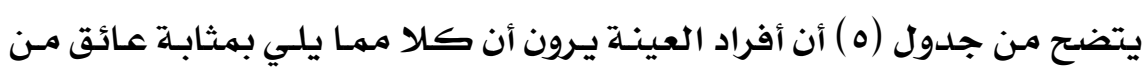

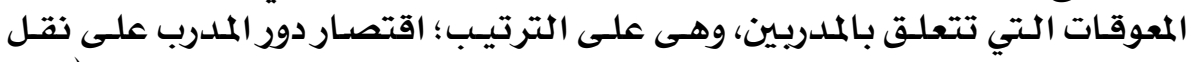

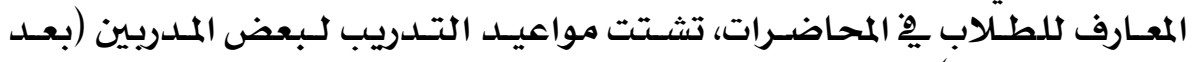

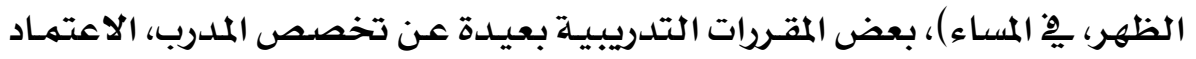

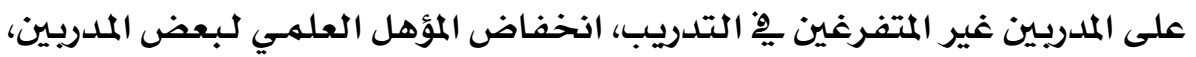

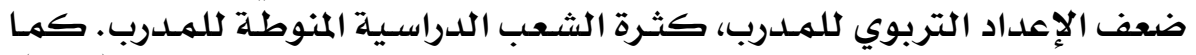

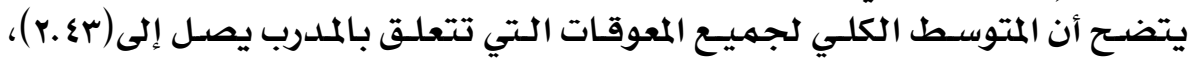

\section{$\varepsilon r \varepsilon$}




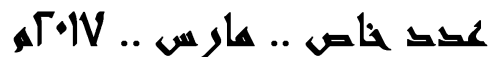

وهذا يعني أن أفراد العينـة موافقون على هـذه المعوقات وهى تمثل مشكلة مهمـة لهمه يُّ العمل بالعمادة.

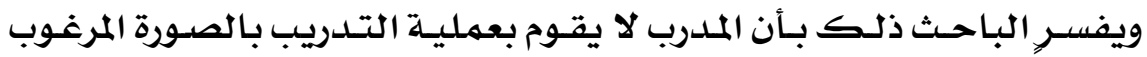

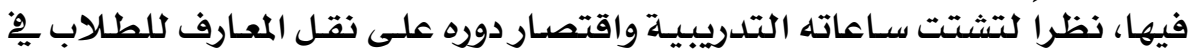

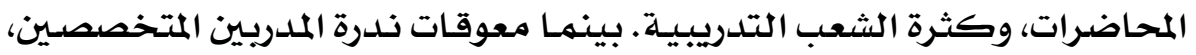

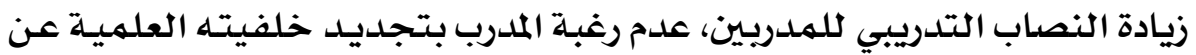

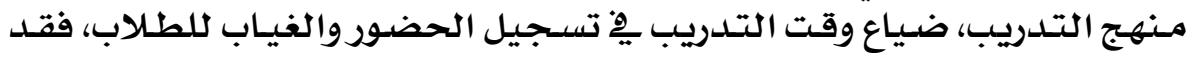

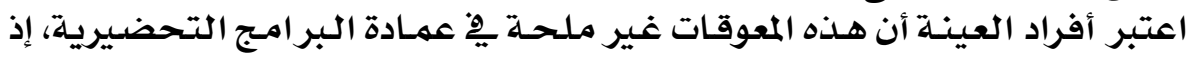

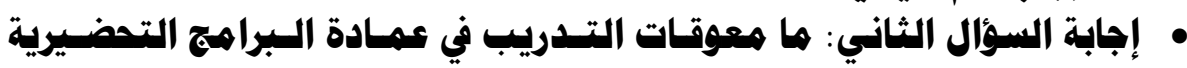
كانت إجاباتهم حيادية.

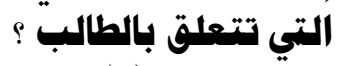

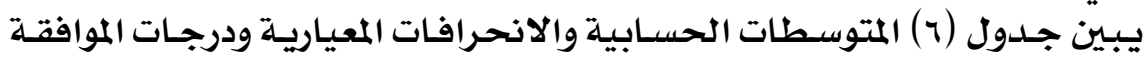

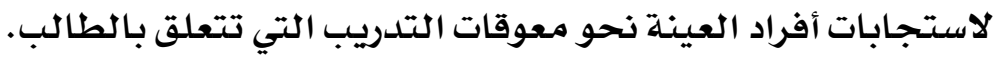
جدول (7) المتوسطات الحسابية والانحرافات المعيارية لمعوقات التدريب الخاصة بالطالب

\begin{tabular}{|c|c|c|c|c|}
\hline الموافقة & الالمعراف & المتوسط & المعوق المـــــــــات & 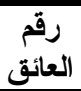 \\
\hline 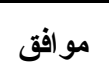 &.$\nvdash \wedge$ & r.71 & العلمية. & $.1 Y$ \\
\hline 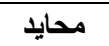 &.$\mu \mathrm{V}$ & r. 1 & اقتصار الطلاب على تحصيل المادة العلمية & $.1 \%$ \\
\hline موافق & 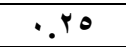 & r..$\wedge$ & | تلني المستوى العلمي للطلاب. & $.1 \varepsilon$ \\
\hline 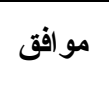 &. .14 & Y.ru & 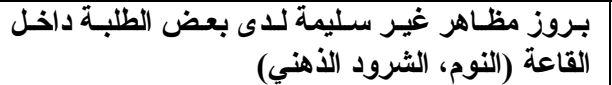 & .10 \\
\hline 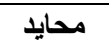 &.$r r$ & 1.77 & ارتفاع أعداد الطلاب في الثعب التريبية. & .17 \\
\hline 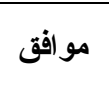 & 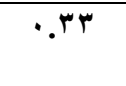 & Y.7V & 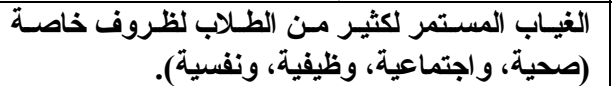 & $.1 \mathrm{~V}$ \\
\hline 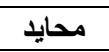 & $.1 \mathrm{r}$ & $1 . \wedge 1$ & ارتفاع النصاب من الساعات لبعض الطلاب. & .11 \\
\hline مو افث &. .0 & Y.OV & الحذف والإضافة من جانب الطلاب لبعض المقررات & .19 \\
\hline موافق &.$r T$ & r.79 & ضعف العلاقة بين الطلاب و المدربين. &.$\varphi$ \\
\hline 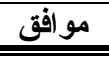 & .1 & Y.YY & استخدام بعض المدربين مصطلحات علمية تخصصية &.$r^{\prime \prime}$ \\
\hline موافق & $\because$.ro & r.r. & درجة الكلية لمعوقات التّريب التي تتعلق بالطالب & \\
\hline
\end{tabular}

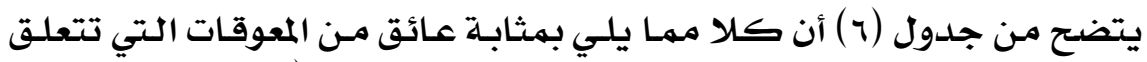

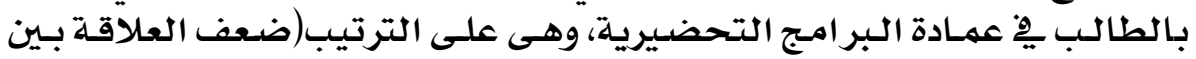

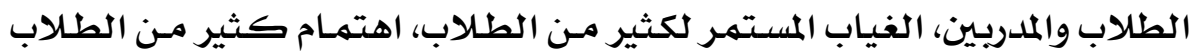

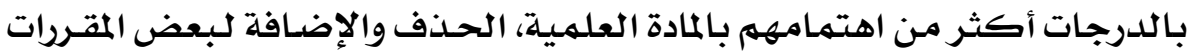

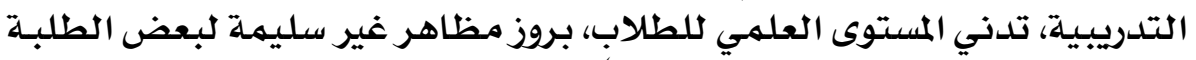

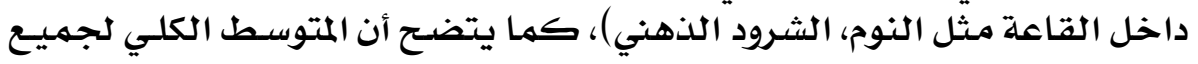

\section{$\varepsilon$ Y०}




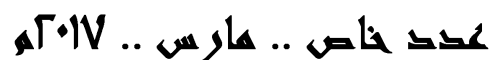

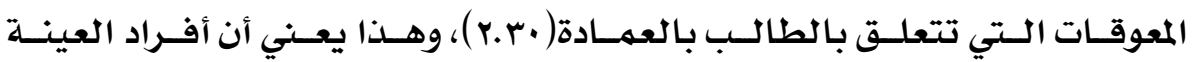

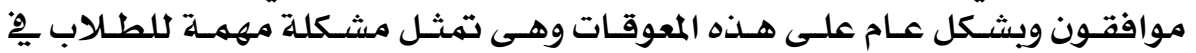

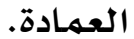

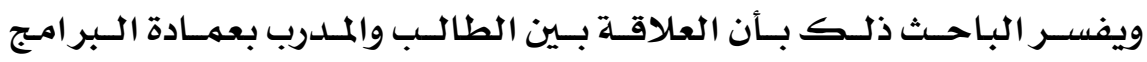

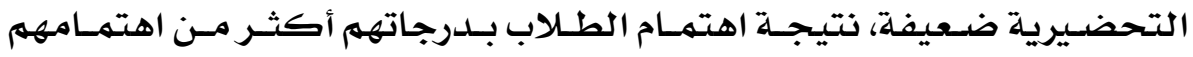

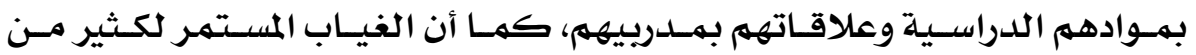

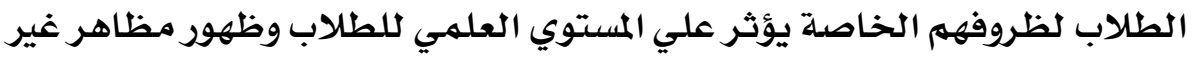

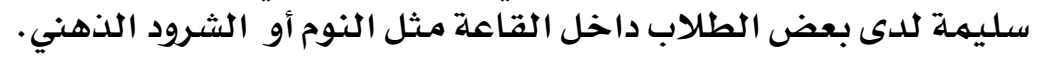

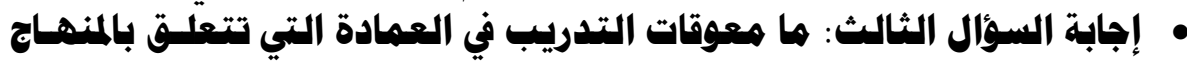
الدراسي؟

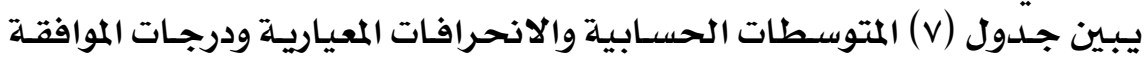

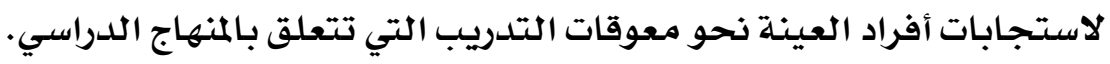

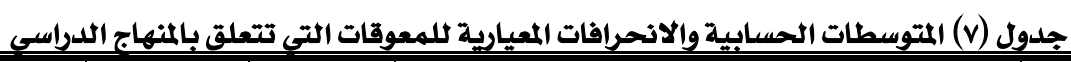

\begin{tabular}{|c|c|c|c|c|}
\hline الموافقة & الآمعراف & المتوسط & المعوقــــات & العائق \\
\hline موافق &. .11 & Y.०A & ضعف التجهيزات التدريبية المتو افرة بالقاعات. &.$r Y$ \\
\hline مو افق &.$Y q$ & Y.0. & قِدِم مفردات المقررات التدريبية . & 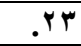 \\
\hline مو افق & $\because \varepsilon$ & Y.A. & قلة تو افر تقتيات التعليم الحديثة للمدربين. & r $\varepsilon$ \\
\hline مو افق &.$Y \wedge$ & Y.VT & بمكتبة العمادة. المر اجـع المناسـبة للمقـررات التـريبيـة &.$r^{\circ}$ \\
\hline مو افق &. $.1 \%$ & Y.०V & قلة توافر القاعات التدريبية الملائمة للتدريب. & .47 \\
\hline مو افق & 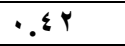 & Y.0. & وجود مقررات تدريبية لا تخدم تخصص الطالب. &.$Y V$ \\
\hline مو افق &.$r \Lambda$ & r.07 & الاعتماد على طريقة المحاضرة في التتريب. &. $\mathrm{r} \Lambda$ \\
\hline مو افق & .11 & r.Mr & 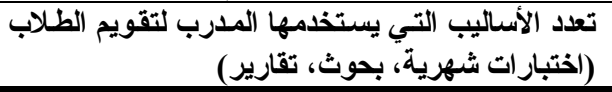 & $.4 q$ \\
\hline موافق &.$r q$ & Y.०V & ية لمعوقات التدريب الخاصة بالمنهاج الدراسي & | (الارج \\
\hline
\end{tabular}

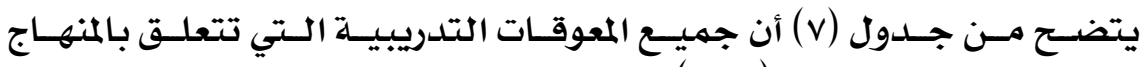

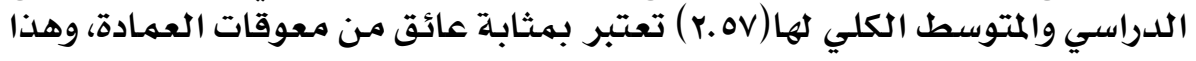

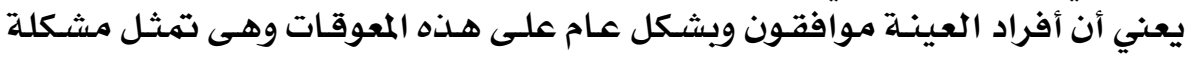

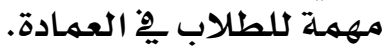

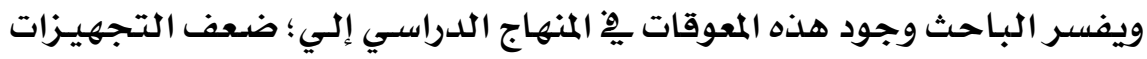

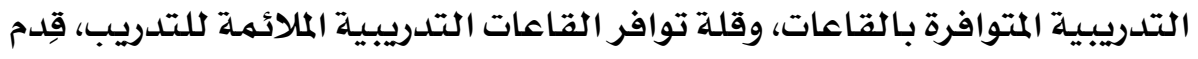

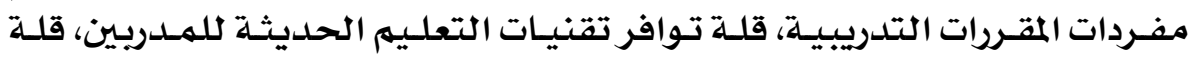

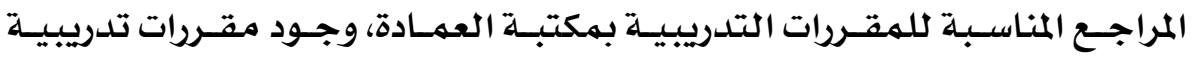

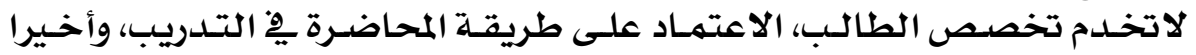

\section{$\varepsilon r q$}




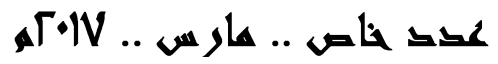

تعـدد الأسـاليب الـتي يستخدمها المدرب لتقويم الطلاب مـن اختبـارات شهرية،

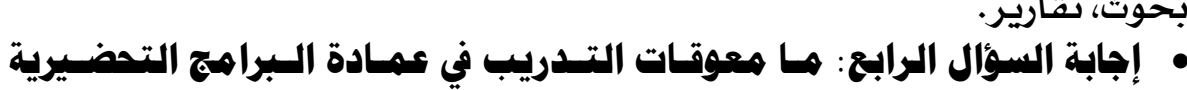
التي تتعلق بإدارة العمادة؛

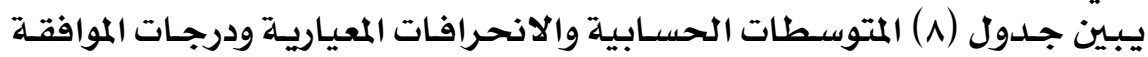

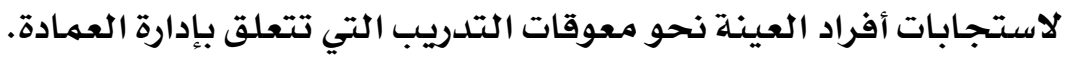
جلدول (^) المتوسطات الحسابية والانحرافات المعيارية لمعوقات التدريب التي تتعلق بإدارة العمادة

\begin{tabular}{|c|c|c|c|c|}
\hline المو افقة & الآحر افياري & المتوسط & المعوق المــــــــات & رقائق \\
\hline 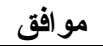 & $\because$ Yr & Y.Y人 & غياب الحافز للمدرب المتميز. &. \\
\hline محايد & $\because$ ro & 1.91 & عدم إتاحة فرص النمو العلمي أمام المدربين. & I \\
\hline موافق & $\because 1 r$ & Y.Y & الار اسـة. &.$\mu r$ \\
\hline 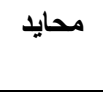 & $\cdot{ }^{M r}$ & r.・A & 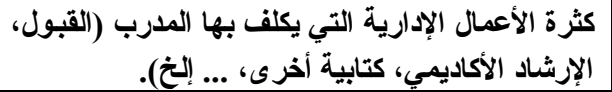 &.$r r$ \\
\hline مو افق & $\cdot r \cdot$ & Y. $\leqslant \varepsilon$ & تدريبه (مثل: تقديم المـدرب بـالتغيير ات التـي سـتؤثر فـي & r \\
\hline مو افق & $\cdot r v$ & Y.O. & 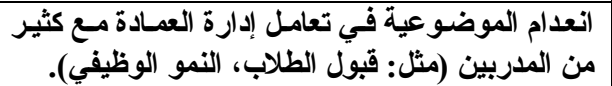 & 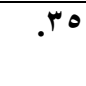 \\
\hline موافق & $\cdot r r$ & r.OY & أمام الطلاب. حضـور المـاربين للمحاضـر ات بشـكل فاضـح &. \\
\hline مو افق & .19 & $r . \mathrm{r \Lambda}$ & كلية لمعوقات التدريب التي تتعلق بإدارة العمادة & 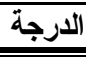 \\
\hline
\end{tabular}

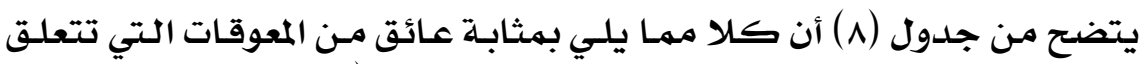

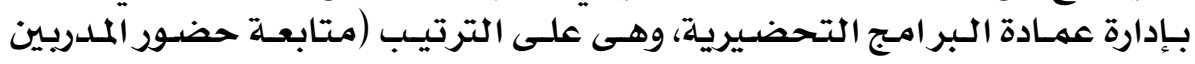

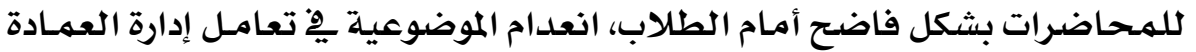

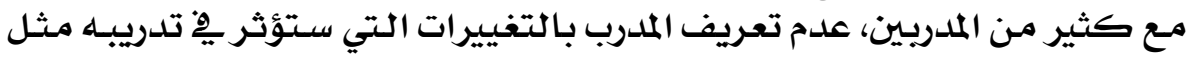

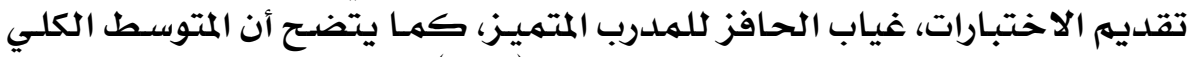

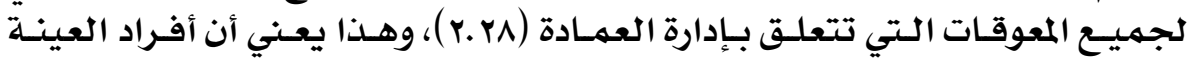

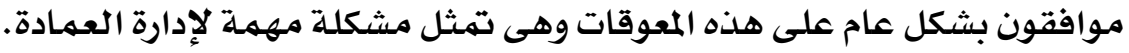

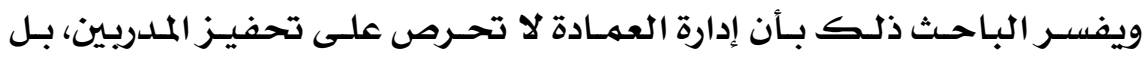

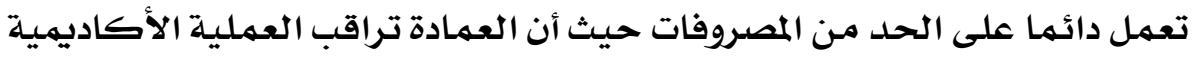

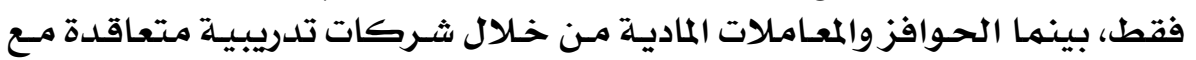

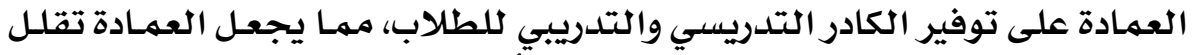

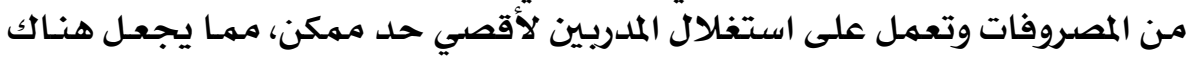

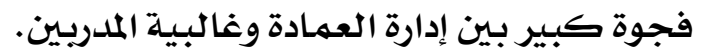

\section{$\varepsilon r V$}




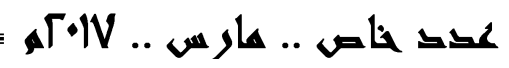

\section{• إجابة السؤال الخاهس: ها هعوقات التدريب في عمهادة الـبراهم التحضيرية}

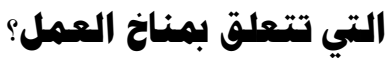

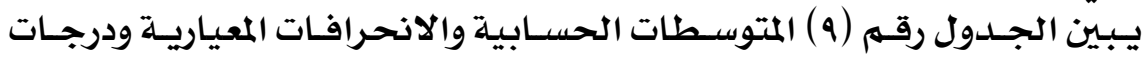
الموافقة لاستجابـات أفراد العينـة نحو معوقات التدريب التي تتعلق بهناخ العهل. جدول ( 9 ) المتوسطات الحسابية والانحرافات المعيارية لمعوقات التدريب التي تتعلق بمناخ العمل

\begin{tabular}{|c|c|c|c|c|}
\hline المو افة درة & الالمحر افياري & المتوسط & المعوق & رقائم \\
\hline محايد &. .11 & $r . \cdot r$ & عدم توافر مكاتب لائقة بالمكانة العلمية للمدربين. &.$\mu v$ \\
\hline 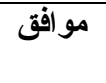 & .11 & r.Mr & العلياب روح المنافسة العلمية بين المدربين في القسم & . \\
\hline موافق & .19 & Y.OY & عدم وجود حوافز للطلاب للتعلم. & $.4 q$ \\
\hline 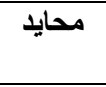 &..$\& 7$ & 9.17 & 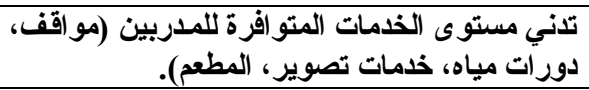 & . . \\
\hline 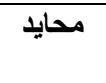 &.$Y \wedge$ & $r . r$ & أكفاء. إرة شئون أعضاء المدربين من قبل موظفين غير &.$\& 1$ \\
\hline مو افق & .11 & r.rq & اللامبـالاة من جاتب إدارة العمـادة بمشكلات المدرب & 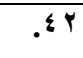 \\
\hline موافق &..$\$ 1$ & $Y .0 \varepsilon$ & ضلعفي العلاقة الاجتماعيـة بين المـدربين في القسـم &.$\leqslant$ \\
\hline مو افق & .09 & Y.7. & ضعف روح التعاون بين المدربين بالقسم &.$\varepsilon \varepsilon$ \\
\hline موافق & 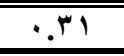 & r.Yr & كلية لمعوقات التدريب التي تتعلق بمناخ العمل & الارجة \\
\hline
\end{tabular}

يتضح من جلدول (و ) أن كالا مهـا يلـي بهثابـة عـائق مـن المعوقات التي تتعلـق

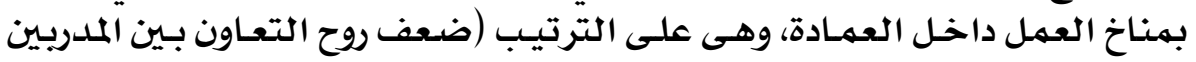

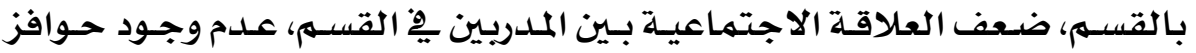

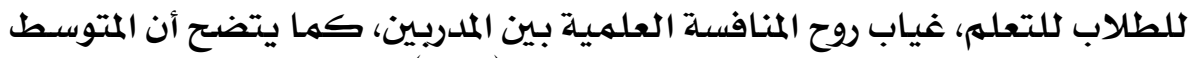

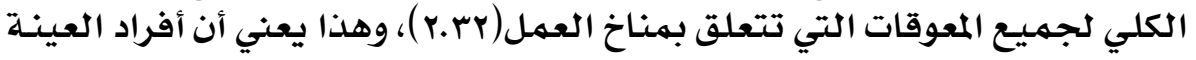

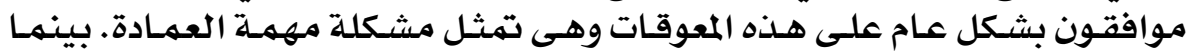

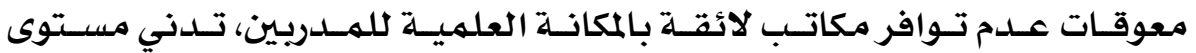

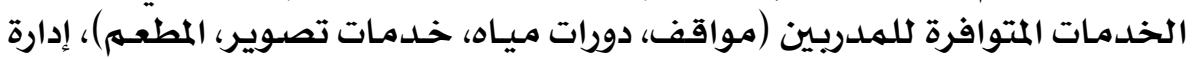

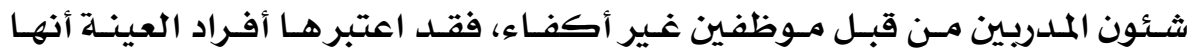

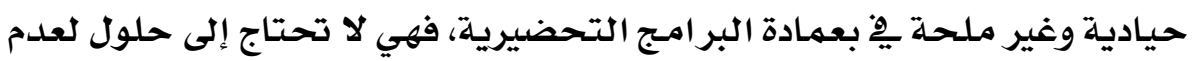
• تأثيرها الكبير عليههم.

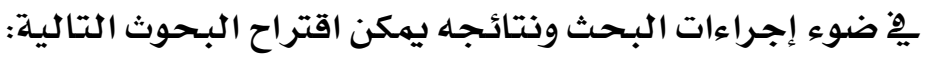

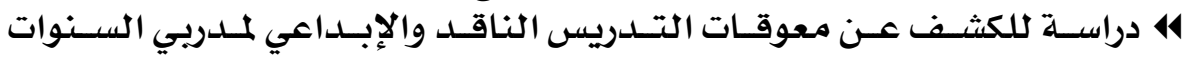
التحضيرية.

\section{$\varepsilon \mu \wedge$}


4 دراسـة اتجاهات الملدريـين يف اسـتخدام الاسـتراتيجيات المعرفيـة ومـا وراء المعرفة

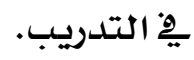

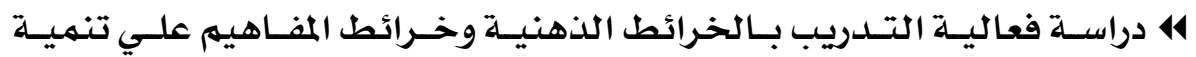
التفكير الناقد والابتكاري. • أولا : المراجع العربية:

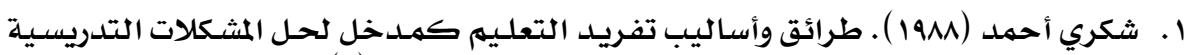

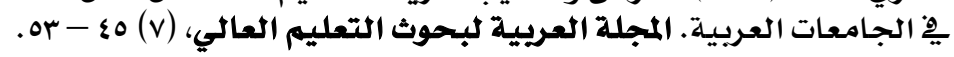

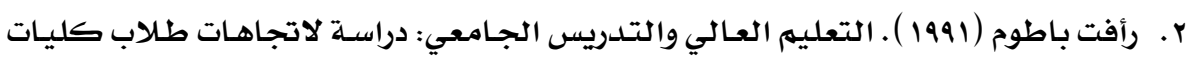

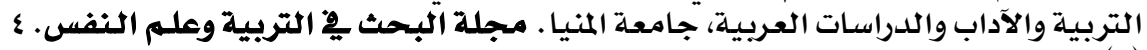
.

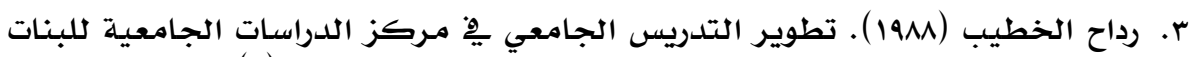

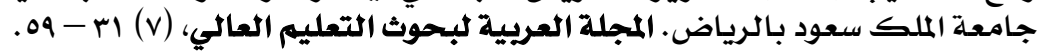

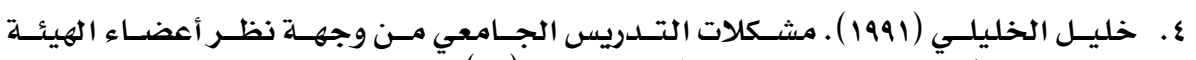

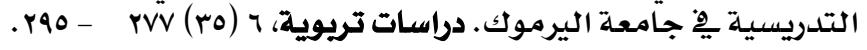

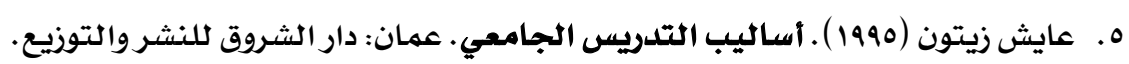

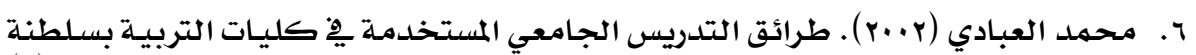

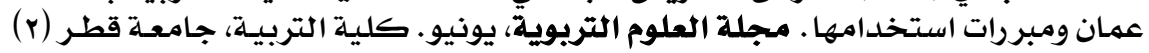
. $\mid r \cdot-\Lambda 1$

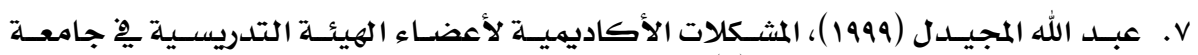

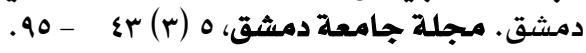

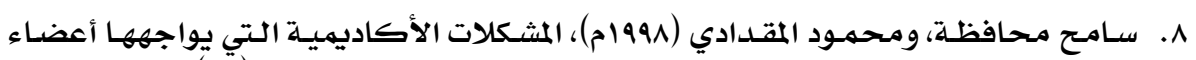

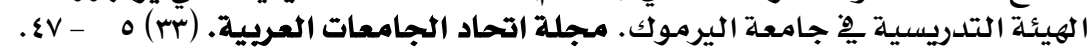

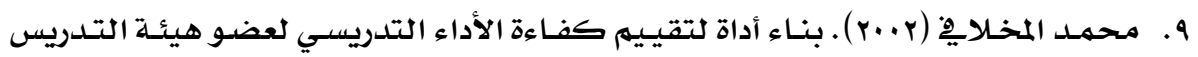

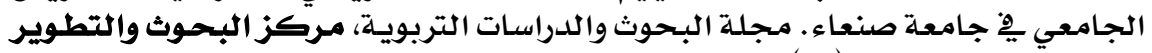

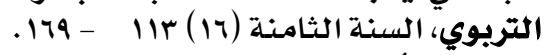

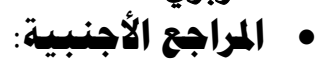

10. Ballantyne, P. et al. (1999). "Researching university teaching in Australia: themes and issues in academics reflections". Studies in higher education. society Ferreseareh into higher education. 24, (2), $237-257$

11. Barnes, L. and Barnes, M. (1993). "A cademic discplene and generalizability of student evaluations of instruction" Research in higher education. 34(2), 135 - 139.

12. Chalmers, D. and Fuller, R. (1996). Teaching for learning at

\section{$\varepsilon+q$}




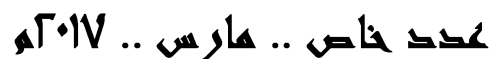

university. Theory and practice. London: Kogan page limited.

13. Orata, P. (1999). "The problem professor of education". The journal of higher education. 70 (5), 589 - 598.

14. Petty, G and Hatcher, I. (1991). "Job satisfaction of faculty from technical institutes. Community colleges and universities" Journal of studies in technical Caucus. 13(4), 361 - 367.

15. Suzanne, Y. and Pate, S. (1999). "Profiles of effective college and university teacher's". Journal of higher education. $671-687$.

\section{溇溇溇洸}

\section{$\varepsilon \varepsilon$.}

